\title{
Perceptions and attitudes of the community in Patutrejo Village, Purworejo, Central Java towards Jalawure
}

\author{
Sanudin ${ }^{*}$ \\ Agroforestry Technology Research and Development Institute, Ciamis, Indonesia
}

\begin{abstract}
Jalawure (Tacca leontopetaloides $\mathrm{L}$ ) is a type of plant that has a habitat in the coastal. Tubers of jalawure are used as alternative food ingredients because they contain starch (amylose and amylopectin). Jalawure is known by the coastal communities in Patutrejo Village Grabag Purworejo, Central Java as mureng. However, many people have not known its use. This study aims to determine the perception and attitude of the communitytowards jalawure. Data was collected through interviews with members of the local community and village head. The data obtained were tabulated and analyzed using a Likert Scale. The study was conducted from October 2020 to March 2021. The results showed almost all respondents know jalawure because they had seen jalawure directly either in the yard or garden or in forest areas in their villages. In total, the perception and attitude of the community on cultivation, benefits, processing, and marketing of jalawure are moderate, this is indicated by the value of all statements which show a value of more than $50 \%$. These positive perceptions and attitudes can be used for the development of jalawure through jalawure cultivation activities so that the community does not depend on jalawure plants that grow wild/ naturally.
\end{abstract}

\section{Introduction}

Even though Indonesia has high biodiversity, the level of food security is still low. This is because the staple food of the Indonesian people is only rice. In fact, foodstuffs derived from carbohydrates from tubers are still widely spread in all corners of Indonesia which can be a source of carbohydrates as an alternative food [1]. Jalawure (Tacca leontopetaloides Kunz.) is a bulbousherb [2, 3], up to 2 meters in height. The tubers are rounded, the midrib leaves are wide, the stems are grooved, and the fruit is dark green [4].

This tuber can store water and carbohydrates. Its advantages have the potential as an alternative carbohydrate source for dry and coastal areas $[3,5,6]$ because a high carbohydrate content, which is equal to $80-88 \%[5,1]$ and because its the composition is comparable to the starch of potatoes and corn and can be used to replace rice and flour as a staplefood [1].However, despite its promise, jalawure is underutilized due to farmers' restricted cultivation [7] and is restricted due to a scarcity of resources [6].

\footnotetext{
* Corresponding author: sanevefa2014@gmail.com
} 
In Indonesia, jalawure is known as Kecondangin Central Java, Mure in Yogyakarta, Jalawure in Garut, Taka in Sumatra, and Lorkongoto'o in Madura[4], Anuwun [8].The community of Patutrejo Village calls it Muring. The mention of the name Muring is rather close to Mure. This is thought to be due to the geographical proximity between Purworejo and Yogyakarta from a geographical aspect. Besides, in Indonesia, jalawurecan befoundgrowing in tropical parts of Africa South Asia, Southeast Asia, northern Australia, Papua, Samoa, and Micronesia [9].

Knowledge of jalawure can help local communities to improve their living standards by creating a wide variety of food products for their market. Its starch flour is also recommended for functional food ingredients[1]. The perceptions or attitudes of local communities can provide insight into people's behaviors and the extent to which they are willing to coexist with a particular resource [10]. This study aims to determine the perception and attitude of the community towards jalawure.

\section{Methods}

\subsection{Time and research location}

The research was conducted from October 2020 to March 2021 in Patutrejo Village Grabag Subdistrict Purworejo District, Central Java Province.

\subsection{Methodology for data collection and analysis}

This research was conducted using a survey method. Determination of respondents using the random sampling method. The respondents in this study consisted of 38 people. The data collected consists of primary data and secondary data. The primary data consists of respondents' characteristics, knowledge, perceptions, and attitudes of the community towards jalawure.

Every question wasrated on a three-point Likert scale $(0=$ not agree, $1=$ do not know, 2 = agree). The level of knowledge/understanding, perception and attitude were categorized based on the percentiles of the total score $(<25$ percentiles $=$ verypoor; $25-50$ percentiles $=$ poor; $51-75$ percentiles $=$ moderate and $>75$ percentiles $=$ good) [11]. The data collected was processed and analyzed using narration and tabulation.

\section{Result and discuss}

\subsection{Characteristics of respondents}

Characteristics of the respondents are presented in Table 1.A total of 38 heads of households or family members were involved in the interviews, $7,8 \%$ being women and $92,2 \%$ men. The averageage of the respondents was 48 years. They can be grouped of production laborage, they were 31 to 50 years old. Living in a productive age group, physically having a greater ability to generatestuff and services [12]. 
Table 1. Characteristics of respondents

\begin{tabular}{|c|c|c|}
\hline No & Characteristics & Number \\
\hline \multirow[t]{4}{*}{1.} & Age (year) & \\
\hline & Minimum & 30 \\
\hline & Maximum & 79 \\
\hline & Average & 48 \\
\hline \multirow[t]{4}{*}{2.} & Level of education (year) & \\
\hline & Minimum & 6 \\
\hline & Maximum & 12 \\
\hline & Average & 9 \\
\hline \multirow[t]{4}{*}{3.} & $\begin{array}{llll}\begin{array}{l}\text { Number } \\
\text { (people) }\end{array} & \text { of family } & \text { dependents } \\
\end{array}$ & \\
\hline & Minimum & 1 \\
\hline & Maximum & 5 \\
\hline & Average & 3 \\
\hline \multirow[t]{4}{*}{4.} & $\begin{array}{l}\text { Land ownership (gardens and paddy } \\
\text { field) (hectare) }\end{array}$ & \\
\hline & Minimum & 0 \\
\hline & Maximum & 1,95 \\
\hline & Average & 0,55 \\
\hline \multirow[t]{4}{*}{5.} & Total land ownership (hectare) & \\
\hline & Minimum & 0 \\
\hline & Maximum & 2,08 \\
\hline & Average & 0,77 \\
\hline \multirow[t]{4}{*}{6.} & Farmingexperience (year) & \\
\hline & Minimum & 8 \\
\hline & Maximum & 45 \\
\hline & Average & 19 \\
\hline
\end{tabular}

The level of education of the respondents was generallyl ow. Most of the formal education respondents were from primary school to junior high school, with an average house hold size of three people. The average amount of land owned per household was 0,55 hectares (garden and paddy fields and the average amount of land owned total (including yard) was 0,77 hectares,with an average farming experience of 19 years. Gardens and ricefields are the dominant sources of income for the respondents. Besides that, there are yards ( 0.13 hectares on average) and ponds ( 0.1 hectares on average). Respondent sacquired land through inheritance $(84,2 \%)$ and village government allocations/bengkok $(15,8 \%)$. Agriculture is the principal economi cactivity of $87 \%$ of the respondents. Farming technology was poor, dominated by the hand hoe and a low level of input used by almost all the respondents. Agriculture is rainfed and farmers follow a rotational system.

\subsection{Knowledge of Community of Jalawure}

Loano the forest area, Forest Management Unit (FMU) South Kedu belongs to Perhutani, is a place for jalawure to grow. The forest area, with an area of 112 hectares, is administratively included in the Patutrejo Village area. Jalawure grows under stands such as malapari (Pongamiapinnata), kayuputih (Melaleuca leucadendron) and other species in the forest area.

Not many people know about Jalawure [4] including the community of Patutrejo Village. The community of Patutrejo Village rarely interacts with the forest area and utilizes forest products because of its forest status as a protected forest. So, almost most people rarely know about jalawure that grows in the forest area. Jalawure, according to its 
characteristics, appears only during the rainy season and at the sametime,o ther types of tubers such as suweg appear.

The growth of jalawure seems to be influenced by the percentage of sunexposure. It usually starts to grow in October to May/June when the percentage of long sunshine is around $60 \%$, then the canopy starts to dry in June/July when percentage of long sunlight increases again to close to $70 \%$ [6]. This condition is in accordance with the results of research by [13]which stated tha tjalawure in South Garut began to grow before the rainy season in October or November.

Information about the marketing of jalawure at the research location is not yet available because jalawure is a species that is not widely known or used, even though it grows wildly around the community. Unlike the case with the existence of jalawure in Garut District, where jalawure is currently starting to be developed and available on the market. Even though the marketing patterns are still very simple, the farmers (in the form of tubers or flour) are sold directly to consumer where the consumers are neighbours or cake makers. The marketing opportunities for jalawure tubers and flour are very open, but due to limited raw materials, the market demand for jalawure has not been fulfilled. The selling price of jalawure flour is currenty unable to compete with other similar flours (wheat, tapioca) due to limited tuber raw materials and production.

\subsection{Community perceptions of Jalawure}

Community perception on jalawure are presented in Table 2.Jalawure is one kind of minor tuber that is wild and not yet widely cultivated [1]. The major constraints facing farmers wishing to grow jalawure and many other indigenous crops is the lack of scientific information [2]. Jalawure in the development process does not require specialt reatment like other agricultural crops, giving about $1 \mathrm{~kg}$ of manure/ hole and planting coincides with the rainy season. The seeds being used are old enough with the size of the seeds being around 50-100 g. Usually the planting is done by using the mounds, the purpose is to make it easier to harvest. The harvesting is done by reaching the age between 8-10 months. Harvesting time of jalawure is the same as harvesting in cassava plantations, but jalawure is harvested at the peak of the dry season, because the starch produced can be maximally produced [14].

Table 2. Community perception on jalawure

\begin{tabular}{|c|l|r|r|r|}
\hline No & \multicolumn{1}{|c|}{ Statement } & \multicolumn{3}{c|}{ Percentage (\%) } \\
\cline { 3 - 5 } & & Agree & \multicolumn{1}{|c|}{$\begin{array}{c}\text { Not } \\
\text { agree }\end{array}$} & $\begin{array}{c}\text { Do not } \\
\text { know }\end{array}$ \\
\hline I. $\quad$ Cultivation of jalawure & 52,63 & 26,32 & 21,05 \\
\hline 1. & Jalawure is a plant that is rarely found & 66,84 & 43,16 & - \\
\hline 2. & The community does not know jalawure yet & 100 & - & - \\
\hline 3. & Jalawure only grows in coastal areas (sandy soil) & 92,11 & 7,89 & - \\
\hline 4. & Jalawure grows wild & 52,63 & 26,32 & 21,05 \\
\hline 5. & Jalawure seeds are easy to obtain & 52,63 & 47,37 & - \\
\hline 6. & Jalawure is easy to grow or cultivate (Placeholder1) & 52,63 & 47,37 & - \\
\hline 7. & Jalawure is easy to care for & 52,63 & 47,37 & - \\
\hline 8. & Jalawure grows well understands & 100 & - & - \\
\hline 9. & Demonstration plots as a means of learning about the & & & \\
\hline & cultivation process & & & \\
\hline II. & Benefit of jalawure & 52,63 & - & 47,37 \\
\hline 1. & Jalawure leaves can be used for animal feed & 100 & - & - \\
\hline 2. & Community is not used to processing jalawure into flour & 52,63 & - & 47,37 \\
\hline 3. & Jalawure flour contains high starch/carbohydrates & \multicolumn{3}{|l}{} \\
\hline
\end{tabular}




\begin{tabular}{|c|l|r|r|r|}
\hline No & \multicolumn{1}{|c|}{ Statement } & \multicolumn{1}{|c|}{ Percentage (\%) } \\
\cline { 3 - 5 } & \multicolumn{1}{|c|}{$\begin{array}{c}\text { Agree } \\
\text { Not } \\
\text { agree }\end{array}$} & $\begin{array}{c}\text { Do not } \\
\text { know }\end{array}$ \\
\hline 4. & $\begin{array}{l}\text { Jalawure can be used as an alternative food substitute for } \\
\text { flour }\end{array}$ & 52,63 & - & 47,37 \\
\hline 5. & $\begin{array}{l}\text { The community does not yet know the benefits of } \\
\text { jalawure }\end{array}$ & 100 & - & - \\
\hline III. & Processing of jalawure & 92,11 & - & 7,89 \\
\hline 1. & To be consumed, jalawure must be processed first & 65,79 & - & 34,21 \\
\hline 2. & $\begin{array}{l}\text { Jalawure flour is easily processed into various forms of } \\
\text { food }\end{array}$ & 65,79 & - & 34,21 \\
\hline 3. & Processing of jalawure into flour is not difficult & 65,79 & - & 34,21 \\
\hline 4. & $\begin{array}{l}\text { Processing jalawure into flour does not require modern } \\
\text { equipment/machines }\end{array}$ & 60,53 & - & 39,47 \\
\hline 5. & Cheap jalawure processing costs & 100 & - & - \\
\hline 6. & $\begin{array}{l}\text { The community does not yet know about } \\
\text { jalawureprocessing }\end{array}$ & & & \\
\hline IV. & Marketting of jalawure & 68,42 & - & 31,58 \\
\hline 1. & Jalawure tubers are easy to obtain & 100 & - & 50 \\
\hline 2. & Jalawure flour is easy to sell & - & - \\
\hline 3. & $\begin{array}{l}\text { The community does not yet know about jalawure } \\
\text { marketing }\end{array}$ &
\end{tabular}

The distribution pattern of jalawure in groups maybe influenced by generative propagation through seeds from the jalawure plant where the number of jalawure seeds is quite large and the number of small tillers is found to be quite dense and relatively the same age, especially in Pantai Sayang Heulang, Garut [15]. The influence of seeds on the distribution of plants in groups was quite large because the seeds did not fall far from their mother, as happened with bamboo plants in Gunung Baung Nature Park [9], according to [3] the clustered distribution pattern of jalawure plants is caused by the large number of jalawure seeds not dispersed far from the parent In addition, information on the role of seeds in the distribution of jalawure plants shows that jalawure can be propagated through seeds even though to producing large tubers takes quite a long time or more than one season.

Based on Table 2, it is known that the public perception of the cultivation, benefits, processing, and marketing of jalawure is moderate. This is indicated by the value of all statements which show more than $50 \%$. This perception can be used for the development of jalawure, coupled with the potential/existence of jalawure around the community. However, jalawure cultivation must continue to be developed so that people do not depend on wild/naturally grown jalawure plants.

Most of the use in jalawure tubers of the Garut community still comes from nature without cultivation, so the iravailability is decreasing[15]. Jalawure cultivation activities are still minimal eventhough many people have used them. People usually take jalawure tubers that grow wild in nature without any effort to preserve them. People are reluctant to cultivate jalawure because it takes too long. Based on preliminary empirical observations, jalawure tubers weighing 2-3 kg per tuber are usually harvested from plants that have gone through two rainy seasons [6].

The mechanical process of scarring, the time needed is faster and the operational funds are less. Previously, the community was still traditional, so that the selling price of Jalawure flour was more expensive than the selling price of wheat flour in the market. Therefore, with improved technology, it was expected that the selling price of jalawure starch flour would be equal to or lowerthan the price of flou $r[14]$. The development of Jalawure needs attention from the local government to improve the economy of coastal 
communities. Jalawure has considerable potential that can be used asa solution to deal with food insecurity.

\subsection{Community attitude of jalawure}

Community attitude of jalawure in presented are Table 3.The attitude of the community towards jalawure is also, as shown in Table 1,moderate, where almost all statements are more than $50 \%$. These positive perceptions and attitudes can be utilized for the development of jalawure, coupled with the potential for jalawure around the community, especially in the Loano RPH forest area.However, jalawure cultivation must continue to be developed so that people do not depend on jalawure plants that grow wild / naturally.

Table 3. Community attitude of jalawure

\begin{tabular}{|c|l|r|r|}
\hline No & \multicolumn{1}{|c|}{ Statements } & \multicolumn{1}{|c|}{ Agree } & \multicolumn{1}{|c|}{$\begin{array}{c}\text { Do not } \\
\text { know }\end{array}$} \\
\hline I. & Cultivation of jalawure & 65,79 & 34,21 \\
\hline 1. & I am willing to collect wild-growing jalawure tubers & 39,47 & 60,53 \\
\hline 2. & I am willing to buy jalawure seeds & 78,95 & 13,16 \\
\hline 3. & $\begin{array}{l}\text { I am willing to plant jalawure on my land because of a } \\
\text { project/activity }\end{array}$ & 78,95 & 13,16 \\
\hline 4. & $\begin{array}{l}\text { I am willing to plant jalawure on my land because of my own } \\
\text { awareness (know the benefits) }\end{array}$ & 52,63 & 47,37 \\
\hline 5. & I am willing to maintain jalawure plants (fertilization, weeding) & 52,63 & 47,37 \\
\hline 6. & I am willing to plant jalawure between other plants & 100 & - \\
\hline 7. & I am willing to learn jalawure cultivation & 100 & - \\
\hline II. & Processing of jalawure & 92,11 & 7,98 \\
\hline 1. & I am willing to learn how to processing jalawure & 100 & - \\
\hline 2. & I am willing to take advantage of the wild growing jalawure & 60,53 & 39,47 \\
\hline 3. & I am willing to take advantage of jalawure that is planted on my \\
& own land & 60,53 & 39,47 \\
\hline 4. & I will process the jalawure into flour myself & 60,53 & 39,47 \\
\hline 5. & I will combine jalawure flour with other food ingredients & 63,16 & 36,84 \\
\hline 6. & I will eat food processed by jalawure flour & 65,79 & 34,21 \\
\hline III. & Marketting of jalawure & 63,16 & 36,84 \\
\hline 1. & I will only use jalawure flour for my consumption \\
\hline 2. & I would sell jalawure flour if there was a market & \multicolumn{2}{r}{} \\
\hline 3. & I will sell groceries from jalawure flour &
\end{tabular}

Based on the measurement of people's perceptions and attitudes towards jalawure which showed a positive value, the research team then followed up by conducting training in jalawure processing to attract more public interest in the cultivation and processing of jalawure by utilizing the potential of jalawure around the community. Jalawure processing training activities involve instructors from agricultural extension agents in Cikelet Subdistrict, Garut District, who are used to training and developing Jalawure, including processing it into flour and processing it into various foods.

Jalawureisused by some people in Garut Selatan[1], Sukabumi, Gunung Kidul, Karimunjawa, Kepulauan Krakatau, Kepulauan Kangean[3], Madura [4], and Kabupaten Kepulauan Talaud Sulawesi Utara[8]. As an alternative to rice and wheat flour, jalawureis an excellent choice for overcoming food instability and famine seasons[14].

The potential jalawure flouris also used as a rawmaterial for making biscuits because it contains amylopectin, whichmakes the biscuits hard to break and crunchy [11], for baby 
meals for children aged 6 months and above, folded cakes, and rolls in Talaud District[8].The people of South Garut, especially in Cikelet Subdistrict, usually use jalawureflour as a raw material for making wet cakes such as trays and pastries such as eggrolls and cheese steaks[15]. In Bangka Belitung, although abundant, but only in certain areas that are recognize and utilized. Also unlike other tubers that have been traded in the market, tacca is only for its own consumption [4].In Madura, jalawure flouris made intovarious foods, such as serpot, eped-eped/eseng-eseng with a mixture of grated coconut and sugar[4].

Tubers of jalawure are processed by the local community in the research sites to serve as a substitute for ricestarch or flour to overcome food shortages and famine [1].Although the tubers are poisonous, the poison is removed by soaking or washing and rinsing the starchy tubers at water repeatedly, after which they can be processed for food. The tuber contains starch, ceryl alcohol, steroidal saponins, and a bitter principle, Taccalin[9].

The training participants totaled 25 people, consisting of community/ farmers, including 15 women, 4 village officials, 7 employees of KPH Kedu Selatan (Perhutani), and 4 agricultural extension agents in Grabag District, Purworejo District. The participants interest in the jalawure processing training was quite high. This was evident from the activeness of the participants in the discussion and the practice of processing jalawure flour into processed food (wet food and dry food), which was an added value that made this training very attractive to the participants.

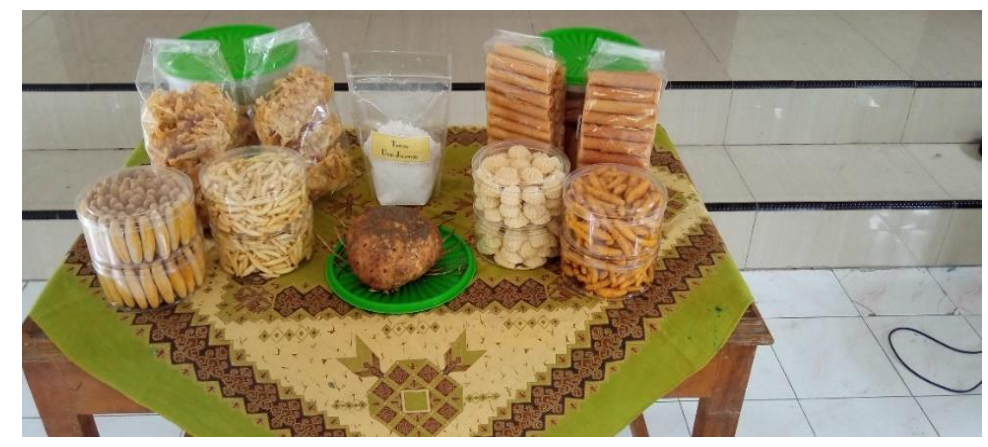

Fig. 1. Jalawure flour dry food

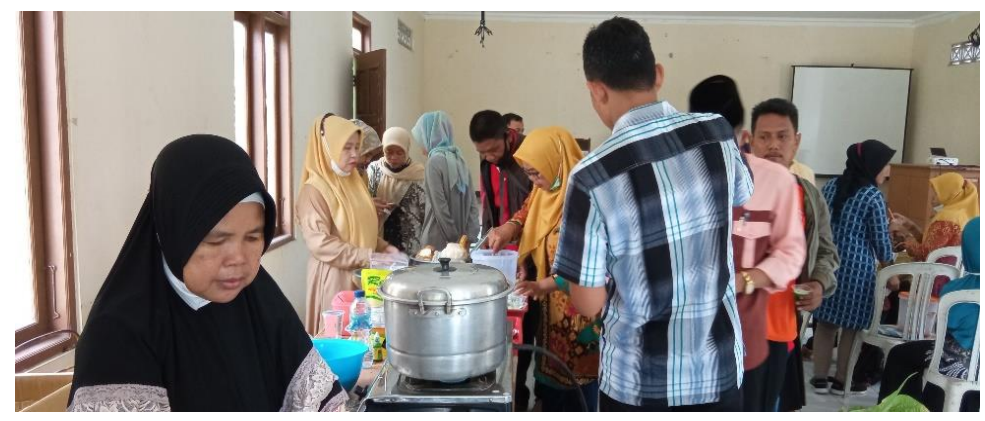

Fig. 2. Jalawure flourprocessing into wet food processing

\section{Conclusion}

The results showed almost all respondents knew jalawure because they had seen jalawure directly either in their yard or garden or in forest areas in their villages. In total, the perception and attitude ofthe community towards the cultivation, benefits, processing, and 
marketing of jalawure are moderate. This is indicated by the value of all statements that show a value of more than $50 \%$. These moderate perceptions and attitudes can be used for the development of jalawure through jalawure cultivation activities so that the community does not depend on jalawure plants that grow wild/ naturally.

Acknowledgement. Research was conducted in Purworejo District,Central Java Province, through cooperation between the Forest TreeSeed Technology Research and Development Instituteand the Sino-ASEAN Network of Forestry Research Institutes (SANFRI) and we thank the Head of Agroforestry Technology Research and Development Institute Ciamis and the Head of Forest Tree Seed Technology Research Bogor, and Mulyono, as Chairman of theFarmer Group, Patutrejo Village, whohave helped in the implementation of research in this area.

\section{References}

1. Wardah, E. N. Sambas, A. Ridwan, D. Ariani. IOP Conf. Series: Materials Science and Engineering 193(2017)

2. T. I. Borokini, A. E. Ayodele.Int. J. Mod. Bot. 2, 97-102 (2012)

3. F. Syarif, P. Lestari, H. Wawo. Ber. Biol.13, 161-71 (2014)

4. S. Susiarti Ber. Biol.14,97-103 (2015)

5. Q. T. H. Vu, P. T. K. Le, H. P. H. Vo, T. T. Nguyen, T. K. M. Nguyen. AIP Conf. Proc.1878 (2017)

6. Ridwan, Wardah, D. Ariani. J. Agron. Indones. Indonesian J. Agron. 48 150-6 (2020)

7. A. F. Martin, B. W. Hapsari, T. M. Ermayanti. IOP Conf. Ser. Earth Environ. Sci.741 (2021)

8. Y. Yenisbar, L. P. Ekowahyuni, U. Y. Pratama. Agrosains J. Penelit. Agron. 22, 52 (2020)

9. M Ardiyani, L.D. Sulistyaningsih,Y. N. Esthi.Ber. Biol. 13 85-96 (2014)

10. A. Mir, Z Rais, Z. R. Mir, A. Noor, B. Habib, G. G. Veeraswami. Bioone Complet.35 392-400 (2021)

11. B.J. Murtani, J.A. Wibowo, C.A. Liu, M. R. Goey, K. Harsono, A. Ayu, P. Mardani, T. Wiguna. Asian J. Psychiatr .48 101912 (2020)

12. A.D. Putri. E-Journal EP Unud. 2, 173-80 (2013)

13. Wardah, D. Ariani. Proceedings of the 5th ASIAHORCs International Symposium. (Bali) (Jakarta, Indonesia: LIPI) 135-49 (2014)

14. Wardah, D. Ariani. IOP Conf. Ser. Earth Environ. Sci. 458 (2020)

15. A. Winara, Murniati. J. Penelit. Hutan dan Konserv. Alam. 15 79-89 (2018)

16. S. Sofiah, D. Setiadi,D. Widyatmoko.Ber. Biol.12, 239-47 (2013) 